\title{
Food for Thought: Hormonal, Experiential, and Neural Influences on Feeding and Obesity
}

\author{
Ilia N. Karatsoreos, ${ }^{1}$ Joshua P. Thaler, ${ }^{2}$ Stephanie L. Borgland, ${ }^{3}$ Frances A. Champagne, ${ }^{5}$ Yasmin L. Hurd, ${ }^{6}$ \\ and Matthew N. Hill ${ }^{4}$ \\ ${ }^{1}$ Department of Integrative Physiology and Neuroscience, Washington State University, Pullman, Washington 99164, ${ }^{2}$ Division of Metabolism, \\ Endocrinology and Nutrition, University of Washington, Seattle, Washington 98109, ${ }^{3}$ Department of Pharmacology and Physiology and ${ }^{4}$ Department of Cell \\ Biology and Anatomy \& Psychiatry, Hotchkiss Brain Institute, University of Calgary, Alberta T2N 4N1, Canada, ${ }^{5}$ Department Psychology, Columbia, New \\ York, New York 10027, and 'Departments of Psychiatry and Neuroscience, Montana Sinai Ichan School of Medicine, New York, New York 10029
}

Obesity is a growing public health problem. Although convenient, the notion that obesity is simply a problem of will power is increasingly antiquated. It is becoming clear that complex interactions of environment, neurohormonal systems, and transgenerational effects directly contribute to obesity. This review highlights data presented at the Society for Neuroscience Annual Meeting in San Diego, California in 2013; and although not meant as an exhaustive review of the area, this reivew will explore seemingly disparate areas of research that, when taken as a whole, illuminate the complex topography of the causes and consequences of obesity. We discuss how disruption of the biological clock, a consequence of modern society, can lead to changes in the brain and periphery that lead to obesity. We explore how obesity can actually cause pathological changes within the hypothalamus of the brain (a key regulator of food intake and metabolic homeostasis). How reward circuitry, particularly the ventral tegmental area, responds to insulin and how these effects modulate feeding and the salience of feeding cues are mechanistically described. We also investigate how nutrition may cross generational boundaries to affect the development and function of offspring, underscoring the long reach of metabolic effects. Finally, the role of the endocannabinoid system is emphasized as a critical node in the transduction of many of these effects. Together, this review should provide perspective into the neural causes and consequences of obesity, and hopefully lead to new areas of interdisciplinary research to tackle this important public health epidemic.

\section{Introduction}

Obesity is a significant public health problem, resulting in a heightened risk of diabetes, heart disease, cancer, and other chronic illnesses. Currently, $68 \%$ of United States adults have a body mass index $>25 \mathrm{~kg} / \mathrm{m}^{2}$ (definition of overweight) and collectively account for an estimated $10 \%$ of annual health care costs $(\sim \$ 147$ billion in 2008). This phenomenon is not restricted to the United States or the developed world, and obesity is on the rise in several developing countries, making it a worldwide epidemic. With the acceleration of obesity rates and few effective obesity treatment options, new strategies are urgently needed. However, gaps in our understanding of body weight control continue to limit progress toward this goal. Although the general public does not usually consider obesity as a "brain disorder," it is important to emphasize that the brain has a central role in the

\footnotetext{
Received Aug. 12, 2013; revised Sept. 17, 2013; accepted Sept. 19, 2013.

Author contributions: I.N.K., J.P.T., S.L.B., F.A.C., Y.L.H., and M.N.H. wrote the paper.

We thank all those working in the respective laboratories that led to the data discussed in this review, the many funding agencies that have contributed to the development of many of these different lines of research, and the Society for Neuroscience for inviting us to present our work at the Annual Meeting, and for the opportunity to contribute this review.

The authors declare no competing financial interests.

Correspondence should be addressed to Dr. llia N. Karatsoreos, Department of Integrative Physiology and Neuroscience, Washington State University, 1815 Ferdinand's Lane, Pullman, WA 99164. E-mail: iliak@vetmed.wsu.edu.

DOI:10.1523/JNEUROSCI.3452-13.2013

Copyright $\odot 2013$ the authors $\quad 0270-6474 / 13 / 3317610-07 \$ 15.00 / 0$
}

development of obesity while also being affected by obesity. As such, the brain and body are part of the "two-way street" of obesity, and exploring the brain mechanisms that contribute to obesity, as well as the effects of obesity on central processes, could offer transformative knowledge and novel solutions to this epidemic.

This review is based upon presentations in the "Food for Thought" minisymposium at the Society for Neuroscience Annual Meeting in San Diego in 2013. The goal of that symposium was to explore the bidirectional relationship between the brain and periphery, and the role of the environment in the development of obesity. Although increased caloric intake (as well as the source of those calories, such as from fat, protein, or carbohydrates) and an increasingly sedentary lifestyle play a central role in metabolic dysregulation, the focus of the present review is on novel interactions between the brain and periphery that may cause or exacerbate the development of obesity. We will explore environmental, experiential, and transgenerational effects, and we outline how these disparate mechanisms can affect brainbody interactions that lead to this rising epidemic.

\section{Circadian influences on obesity}

Environmental modulators of obesity have been an area of interest, spanning from environmental stressors to social factors. However, recent work has suggested that circadian (daily) rhythms, and disruption of these rhythms by light, could also be 
a major contributor to the susceptibility of an individual to develop obesity. Circadian rhythms in physiology and behavior are both phylogenetically ancient and incredibly well conserved between species. A master clock in the suprachiasmatic nucleus (SCN) of the hypothalamus generates circadian rhythms in mammals and is also responsible for synchronizing these rhythms to the external light-dark cycle. In addition, "peripheral oscillators" throughout the brain and body are responsible for setting "local time" in various organs and tissues and are synchronized by numerous inputs, including rhythms of circulating glucocorticoids (Balsalobre et al., 2000; Balsalobre, 2002), feeding (Mendoza et al., 2005), and body temperature (Saini et al., 2012).

At the molecular level, a significant body of evidence supports a role for circadian "clock genes" in metabolic function. Work by Turek et al. (2005) has shown that mice carrying the CLOCK mutation, which alters the functioning of the central pacemaker and peripheral oscillators, become obese compared with their wild-type (WT) littermate controls. Moreover, when exposed to a high-fat diet (HFD), these mice become obese more rapidly and to a greater extent than normal chow-fed mice (Turek et al., 2005). More recently, elegant work exploring the role of circadian clock genes at the tissue level has uncovered an important role in the development of obesity and diabetes. Mice with a conditional BMal1 locus mutation only in the islet cells of the pancreas develop both obesity and Type 2 diabetes several weeks after gene deletion (Marcheva et al., 2010). This clearly demonstrates an important role for the circadian clock, at both the tissue and whole organism levels, in processes that contribute to obesity.

Since the advent of electric lighting and modern industry, humans have broken the once-tight connection between the external solar day and our daily activities. These changes have happened rapidly over the past 100 years and thus represent an incredibly fast environmental change when viewed in the context of the evolution of the circadian clock. There is a growing body of work that links changes in circadian light-dark cycles to physiological and psychological disorders, and more work is necessary to explore the mechanisms by which these altered cycles affect metabolic function. Investigating how environmental mediators affect the development and trajectory of dysregulated metabolic function and obesity is an important compliment to the molecular and genetic work, as specific genetic mutations are less likely to be direct mediators of obesity in human populations, whereas environmental mediators are more pertinent contributing factors. Karatsoreos et al. (2011) have demonstrated that housing WT C57BL/6 mice in a $20 \mathrm{~h}$ light-dark cycle $(10 \mathrm{~h}$ light: $10 \mathrm{~h}$ dark) leads to weight gain, metabolic dysregulation as measured by leptin and insulin levels, and an altered relationship between plasma insulin and glucose, suggesting a prediabetic or diabetic state. More recently, this group has further demonstrated that the obese phenotype is associated with a blunting of the rhythm of "clock gene" expression (e.g., Period1, Period2, Cryptochrome1, and Cryptochrome2) in the liver and white adipose tissue, as well as a flattening of the rhythm in plasma corticosterone (I. N. Karatsoreos, unpublished observation). How disruption of central and peripheral clock function (as measured by hormone and clock gene rhythms) contributes to the development of the metabolic phenotype remains unknown. Probing the mechanisms by which altered glucocorticoid rhythms could affect metabolic function both in the periphery and in the brain should yield important insights. Recent work from this group has also demonstrated a potential role of the endocannabinoid (eCB) system in this process, as cannabinoid receptor 1 (CB1r) deficient mice are protected against the effects of circadian dysregulation on obesity and metabolic parameters; the nature of how eCBs impact these processes has yet to be determined, but these data do highlight the potential contribution the eCB system.

\section{Neurohormonal regulation of feeding and obesity}

The hypothalamus has been a major focus of research on obesity, as this brain area contains numerous interacting systems that regulate feeding, satiety, and other motivational states. It is also the region containing the SCN master circadian clock, and the paraventricular nucleus, a central node in the hypothalamicpituitary-adrenal axis that regulates glucocorticoid secretion. In addition, the hypothalamus contains key neurons that oversee the regulation of energy homeostasis (i.e., the precise matching of caloric intake with energy expended that normally keeps body weight stable over many years). Numerous molecules have effects on metabolic function and energy balance, with some 100 unique molecules having been identified to date (Wilding, 2002; Fick and Belsham, 2010). It is beyond the scope of this review to cover even a fraction of these compounds, but glucose, insulin, ghrelin, and leptin will be our focus. Glucose is obviously an important metabolic signal, and glucose sensing at the level of the CNS has clear effects on peripheral function through the autonomic nervous system. Glucose sensing neurons are found in many hypothalamic areas, including the arcuate nucleus (ARC), dorsomedial hypothalamus, paraventricular nucleus, ventromedial hypothalamus, and the lateral hypothalamic area, regions that are clearly involved with feeding and energy homeostasis (for review, see Williams et al., 2001). Insulin, a central hormone in the regulation of glucose homeostasis, also gains access to neural metabolic systems through the hypothalamus, particularly the ARC, which is rich in insulin receptors. Insulin activity in the CNS is important in the regulation of body weight in rats and can accentuate the effects of cholecystokinin on feeding (Chavez et al., 1995; Figlewicz et al., 1995). Several studies also indicate the importance of insulin signaling in the ARC in the integration of several peripheral metabolic signals (for review, see Kohno and Yada, 2012; Williams and Elmquist, 2012). One such peripheral signal is ghrelin, a gut peptide that has come to be considered as a "hunger hormone" (Williams and Elmquist, 2012). This peptide can activate NPY neurons in the ARC while also inhibiting proopiomelanocortin ARC neurons (Horvath et al., 2001). Importantly, ghrelin increases food intake and adiposity through a putative hypothalamic route (Williams and Elmquist, 2012) and may counteract the effects of insulin and leptin signaling in the hypothalamus (Horvath et al., 2001; Zigman and Elmquist, 2003).

One focus of this review is the hypothalamic action of the hormone leptin, a peptide hormone secreted from adipose tissue that can act in the hypothalamus to affect feeding. Ordinarily, leptin levels increase in proportion with adiposity and provide a negative feedback signal to neurons of the hypothalamus that regulate energy balance (Myers et al., 2008). This allows lean individuals to resist changes to their body weight despite access to highly palatable, high-calorie foods. In contrast, obese individuals overeat despite elevated leptin levels, suggesting that hypothalamic leptin resistance plays a central role in their susceptibility to weight gain (Myers et al., 2008). A prevailing model forwarded to explain this difference (i.e., the mechanism underlying obesity) involves resistance to the body weight-maintaining action of the hormone leptin. However, selective leptin resistance in the periphery and the CNS adds a level of complexity to this model (Correia et al., 2002; Mark et al., 2002) and can occur at different levels of the leptin signaling cascade (for review, see Könner and 
Brüning, 2012). Thus, determining the underlying causes of leptin resistance and developing therapies to reverse it are active areas of research.

Recent work has provided a potential mechanism that contributes to the development of leptin resistance and obesity (Thaler and Schwartz, 2010; Thaler et al., 2012). As rats overeat during the first few days of HFD, they manifest increased hypothalamic-pituitary-adrenal and inflammatory responses. With sustained consumption of HFD, 25\% of the critical weightreducing (proopiomelanocortin) neuronal population is lost (Thaler et al., 2012), leading to reduced responsiveness to leptin and presumably increased susceptibility to obesity. As with other conditions involving brain injury, such as stroke, multiple sclerosis, and Alzheimer's disease, this neuronal damage triggers a CNS-specific wound healing response involving neighboring astrocytes and microglia. This "reactive gliosis" is observable specifically within the hypothalamus, and is not a brain-wide response. Remarkably, gliosis is also seen on MRI scans taken from obese mice and humans (Thaler et al., 2012), suggesting that this damage process may be a common mechanism underlying obesity. Thus, overconsumption of a fat-rich diet may elicit potentially permanent changes in the hypothalamus that promote obesity. More optimistically, these findings provide a new direction for obesity drug design, shifting away from the current emphasis on improving leptin sensitivity toward targeting the structural changes of obesity, including neuronal damage and reactive gliosis. Currently, tools are being developed to modify glial cell function both to harness the neuroprotective capacity of these cells as a potential obesity treatment and to clarify the role of glia in energy homeostasis more generally.

Another mechanism linking leptin signaling within the hypothalamus and the regulation of weight and feeding is the eCB system, which has already been mentioned above as an important regulator of feeding and metabolism (Silvestri and Di Marzo, 2013). Di Marzo et al. (2001) demonstrated a very clear inverse relationship between leptin and $\mathrm{eCB}$ activity in the regulation of feeding. Specifically, administration of leptin reduces eCB content in the hypothalamus in tandem with reductions in feeding (Di Marzo et al., 2001). Further, food deprivation results in a reduction in leptin and a concomitant increase in $\mathrm{eCB}$ levels in the hypothalamus (Di Marzo et al., 2001). This release of eCB signaling by a reduction in leptin contributed to the hyperphagic response to food deprivation as blockade of CB1r signaling suppressed the rebound feeding that occurred after food deprivation (Di Marzo et al., 2001). Continuing this line of investigation, Hill and colleagues (unpublished observations) have found that one of the mechanisms by which leptin regulates eCB signaling is through an induction of eCB hydrolysis. Specifically, the enzyme fatty acid amide hydrolase (FAAH) is responsible for the hydrolysis of the eCB anandamide (AEA) (Cravatt et al., 2001). In response to leptin administration, Hill et al. (manuscript in preparation) found a rapid increase in the hydrolytic activity of FAAH within the hypothalamus that was met by a reduction in the tissue levels of AEA. Consistent with this finding, leptin-deficient animals exhibited reductions in the constitutive levels of FAAHmediated AEA hydrolysis and a basal increase in AEA content in the hypothalamus (Hill et al., manuscript in preparation). The relevance of this relationship between leptin and FAAH was demonstrated by an additional study, which found that the ability of leptin to suppress feeding and weight gain after a period of food deprivation was completely blocked by preadministration of a FAAH inhibitor (Hill et al., manuscript in preparation), indicating that one of primary mechanisms driving the anorectic actions of leptin is an activation of FAAH and a suppression of AEA signaling. This is consistent with previous reports demonstrating that local AEA administration into the hypothalamus can induce feeding, even in presated animals (Jamshidi and Taylor, 2001). As the association between leptin and FAAH is important for the regulation of feeding, it is not surprising that the induction of FAAH by leptin also develops resistance after high fat feeding. Specifically, 19 week exposure to an HFD diet resulted in a basal increase in AEA levels in the hypothalamus and a complete loss of the ability of leptin to induce FAAH activity (Hill et al., in manuscript preparation). As such, there appear to be multiple mechanisms by which leptin resistance within the hypothalamus occurs, and both inflammation and eCB signaling, as well as possible interactions between these systems, may be important in these domains.

Although hypothalamic systems clearly contribute to the development of obesity and can be the target of factors of obesity, other brain areas are clearly involved. As previously mentioned, normal feeding is regulated by circulating peptides (e.g., insulin and leptin) that transmit satiety signals to the brain. Insulin gains access to the brain by active transport across the blood-brain barrier (Woods et al., 2003) and its effects are mediated by signaling through insulin receptors expressed throughout the brain, including the ventral tegmental area (VTA), a critical site for reinforcement of reward seeking. Behavioral evidence suggests that insulin may act in the VTA to suppress aspects of feeding. Insulin administered directly into the VTA inhibits opioid-induced feeding (Sipols et al., 2002) as well as palatable food eating after satiation (Mebel et al., 2012).

Interestingly, insulin in the VTA decreases anticipatory activity as well as conditioned place preference for food. Both of these tasks involve the learned association between the food and context, but during testing, the measurements are taken in the absence of food consumption. In contrast, insulin in the VTA did not alter effort to obtain food as measured by the breakpoint in a progressive ratio self-administration paradigm, even when the motivational limit of the reinforcer was enhanced (Labouèbe et al., 2013). Although these three paradigms overlap in that animals learn associations between a stimulus (i.e., sight/smell in the anticipatory activity paradigm; context in the CPP paradigm; lever in the self-administration paradigm) and the food reward, the progressive ratio task differs such that mice consume the food during the task and engage in escalating effort to obtain the reinforcer. It is unlikely that postconsumatory effects of the food are counteracting intra-VTA effects on the progressive ratio task because intra-VTA insulin can reduce palatable food eating in sated animals (Mebel et al., 2012) and opioid-induced feeding (Sipols et al., 2002). Thus, insulin action in the VTA may serve to suppress processes involved in learned associations between visual and/or olfactory stimuli and food rather than those mediating effort required to obtain food.

Synaptic strengthening of dopamine neurons in the VTA and consequent phasic dopaminergic output is associated with learned associations of cues with rewards (Stuber et al., 2008). Consistent with behavioral data demonstrating that intra-VTA insulin suppresses the salience of food-predicting cues, insulin reduces excitatory synaptic transmission onto dopamine neurons of the VTA (Labouèbe et al., 2013). This reduction in synaptic efficacy is long lasting and selective to excitatory inputs to the VTA. Insulin receptor activation leads to a postsynaptic activation of insulin receptor tyrosine kinase, AKT and mTOR signaling, which in turn increases synthesis of the eCB 2- 
arachidonyl glycerol, leading to a retrograde inhibition of glutamate release via $\mathrm{CB} 1 \mathrm{r}$ activation. Interestingly, $1 \mathrm{~h}$ access to sweetened high fat food occludes insulin induced long-term depression and increases eCB signaling resulting in decreased presynaptic glutamate release. This effect correlates with elevated plasma insulin levels and reverses an hour after the sweetened high fat food exposure when insulin levels are returned to baseline (Labouèbe et al., 2013). Together, insulin action in the VTA either exogenously applied or endogenously induced by a caloric meal transiently suppresses excitatory inputs (possibly relaying information about food-related cues) to VTA dopamine neurons.

In addition to insulin-induced long term depression at excitatory synapses onto dopamine neurons, leptin also suppresses synaptic transmission at these synapses (Thompson and Borgland, 2013). Although leptin can act postsynaptically on dopamine neurons to reduce firing rate (Trinko et al., 2011), leptin also acts presynaptically to inhibit glutamate release onto dopamine neurons via PI3K and JaK2 tyrosine kinase signaling (Thompson and Borgland, 2013). Insulin in the VTA reduces somatodendritic dopamine concentration because of an increase in the number or function of dopamine transporters resulting in increased reuptake of dopamine at higher evoked dopamine concentrations (Mebel et al., 2012). Mice lacking leptin (Lep ${ }_{\mathrm{ob} / \mathrm{ob}}$ ) have decreased content of somatodendritic vesicular dopamine (Roseberry et al., 2007) and reduced evoked dopamine release in the nucleus accumbens (Fulton et al., 2006). Furthermore, in contrast to insulin, intra-VTA leptin decreases food consumption (Hommel et al., 2006) and leptin receptor b knockdown in the VTA increases effort to obtain palatable food reinforcers (Davis et al., 2011). Thus, although leptin and insulin can act as satiety signals within the hypothalamus, these peptides act in parallel, but through differing mechanisms in the VTA to inhibit aspects of ingestive behavior.

In addition to insulin-induced suppression of excitatory synaptic transmission, insulin in the VTA reduces both somatodendritic and terminal dopamine output. Insulin reduction in somatodendritic dopamine is the result of an increase in number or function of dopamine transporters resulting in increased reuptake of dopamine at higher evoked dopamine concentrations (Mebel et al., 2012). Using fast-scan cyclic voltammetry in anesthetized animals, intra-VTA insulin concentration-dependently reduces evoked dopamine release in the nucleus accumbens (Borgland et al., unpublished observation). Together, these data suggest that insulin acts in the VTA to reduce excitatory synaptic efficacy and dopaminergic output. Furthermore, insulin in the VTA likely reduces the salience of cues associated with food thus promoting satiety after a meal.

\section{Transgenerational epigenetic regulation of metabolism and reward circuitry}

Although nutrition during the course of one's own lifespan will most certainly have an impact on the development of obesity, there is increasing evidence that these "nutritional effects" may have consequences for the health and development of subsequent generations of offspring. For example, archival data from Sweden indicate that food availability of grandfathers is associated with the risk of diabetes and cardiovascular disease as well as mortality in grandsons (Pembrey et al., 2006; Kaati et al., 2007). It is important to consider that this effect may be associated with reduced birth weight, as evidenced in elegant studies conducted by the Southampton research group (Phillips et al., 1998, 2000; Reynolds et al., 2001). Nevertheless, this clearly indicates long- term effects of nutritional status on physiology. In laboratory rodents, males exposed to prenatal dietary restriction (through reductions in caloric intake of their mother during late gestation) sire offspring with reduced birth weights and impaired glucose tolerance (Jimenez-Chillaron et al., 2009). Conversely, neonatal overnutrition of male mice can induce insulin resistance and glucose intolerance in their male offspring (Pentinat et al., 2010). In laboratory mice, maternal HFD consumption from preconception to the weaning period leads to increased body length and reduced insulin sensitivity in offspring and grand-offspring; transmission of these effects to $\mathrm{F} 3$ generation female offspring has been observed through the patriline (Dunn and Bale, 2009, 2011), although not all of the changes observed in F1 are maintained through F3.

Evidence for the paternal transmission of the effects of nutrition, toxin exposure, and social experiences (Curley et al., 2011) has led to increased speculation regarding the transgenerational inheritance of epigenetic modifications within the male germline. Epigenetic mechanisms (i.e., DNA methylation, histone modifications, microRNAs) have emerged as dynamic pathways through which environmental experiences can come to be integrated within our biology, leading to variation in neurobiology, behavior, and health (Jirtle and Skinner, 2007; Champagne, 2010). Thus, in contrast to the historical view that epigenetic variation is erased at the time of fertilization, there appears to be transmission of this variation to subsequent generations, which may account for the paternal nutritional effects evident in offspring and grand-offspring.

Champagne et al. have previously shown that males that experience a lifetime of social enrichment sire offspring with elevated weaning weights compared with the offspring of males exposed to a lifetime of social deprivation (Mashoodh et al., 2012). Although these mates have only a brief contact with females during mating and no contact with offspring, females mated with socially enriched males were found to exhibit increased maternal care toward his offspring, a suggestion of a differential allocation effect, and this change in postnatal maternal behavior was correlated with indices of anxiety-like behavior in the males (Mashoodh et al., 2012). Although this study does not preclude the potential influence of inherited epigenetic variation, it does demonstrate the importance of considering paternal-maternal-offspring interactions when considering the mechanism linking paternal experience to offspring development.

Current work is exploring the impact of paternal nutrition from both an epigenetic and maternal effects perspective to evaluate the pathways through which offspring development is altered. Using a food restriction paradigm, in which adult males experience a $15-20 \%$ reduction in caloric intake for 3 weeks (before mating), preliminary data suggest that food-restricted males are more preferred as mates (using a mate preference test) despite exhibiting indices of increased anxiety-like behavior. Moreover, females who are mated with food-restricted males experience increased weight gain during pregnancy and engage in a higher frequency of nursing behavior toward offspring during the postnatal period. Using embryo transfer, the role of mate choice/ preference versus direct influence of food-restricted male sperm is being explored. Previous studies using in vitro fertilization as a tool for eliminating the possible influence of maternal effects have found reduced transmission of paternal effects (induced by male exposure to social stress) to offspring after this manipulation (Dietz et al., 2011), suggesting the potential for both epigenetic and maternal factors in the transmission of 
these phenotypes. As such, a similarly complex route of transmission of paternal food restriction is predicted and emphasizes the need to think more broadly about the mechanisms of inheritance. In the context of this review, it is important to emphasize that paternal effects are emerging as an intriguing influence on offspring development, and there is increasing evidence for the relevance of these effects in understanding the origins of metabolic syndrome and obesity. A real life example of this association is the finding that, in humans, an early onset of paternal smoking predicts increased body mass index in sons (Pembrey et al., 2006).

Expanding on the epigenetic and transgenerational effects that could impact the feeding behavior and metabolism of the offspring is research that has examined the effects of drug use on changes in reward circuitry, which could manifest as behavioral differences in food seeking behavior or hedonic feeding. Like the association of paternal smoking with body mass index in male offspring in humans, another association seems to emerge with the consumption of cannabis. Cannabis mediates its effects through engagement of the eCB system, which has already emerged several times in this review as an important regulator of feeding and metabolism. Particularly relevant to transgenerational epigenetic transmission is the fact that, in addition to the regulation of feeding and metabolism (Silvestri and Di Marzo, 2013), the eCB system is well documented to be involved in gametogenesis where it has been shown to impact DNA remodeling in reproductive cells (Chioccarelli et al., 2010). It now evident that the main psychoactive component of cannabis, $\Delta^{9}$-tetrahydrocannabinol (THC), can have a protracted effects later in life as a consequence of prenatal and adolescent exposure (Jutras-Aswad et al., 2009; Chadwick et al., in press). Emerging evidence from Hurd et al. (Dinieri and Hurd, 2012; Tomasiewicz et al., 2012) also shows that adolescent THC exposure alters the normal epigenetic landscape in the mesolimbic reward-related subregion of the striatum in adulthood. The important contribution of the eCB system in gamete function and neurodevelopment raises the question as to whether transmission of a cannabis-induced epigenetic milieu can contribute to behavioral abnormalities in subsequent generations.

In current studies by Hurd and colleagues, F1 offspring with parental THC exposure (administered during adolescence and mated as adults; offspring raised by drug-naive surrogates) were observed to have impaired reward motivation and a spectrum of anxiety/compulsive behaviors (Szutoritz et al., in revision). Moreover, these animals had molecular and functional disturbances in the striatum, a region rich in CB1r and central to goaldirected and habitual behaviors. Striatal impairments were particularly evident in dysregulation of glutamatergic gene expression and long-term depression, findings that would be predictive of impaired synaptic plasticity. The functional relevance of these changes to feeding and metabolism has yet to be investigated, but intriguingly, F1 offspring without direct exposure to THC themselves have increased body weight (Szutoritz et al., in revision), suggesting that parental germline exposure could potentially induce epigenetic inherited metabolic dysregulation, possibly mediated through alterations in $\mathrm{eCB}$ function.

In conclusion, obesity is often viewed in the general public as a consequence of will power and uncontrolled eating; however, it is becoming increasingly apparent that many other factors can influence feeding behavior, metabolism, and energy balance. The aim of this review was to provide an overview of some of the novel scientific perspectives on factors that can influence feeding and metabolism. For more comprehensive reviews on the topics presented, readers are pointed toward excellent work on circadian rhythms and metabolism (Buijs and Kalsbeek, 2001; Bass and Takahashi, 2010; Bass, 2012), hypothalamic mechanisms of obesity (Thaler and Schwartz, 2010; Velloso and Schwartz, 2011), the interaction between obesity and reward circuits (Kenny, 2011; Stice et al., 2012), and transgenerational effects of nutrition and metabolism (Dunn et al., 2011; Youngson and Morris, 2013), as a start.

Variables, such as circadian dysregulation and epigenetic transmission, demonstrate that some of these contributors to obesity may be beyond an individual's immediate control and can be heavily influenced by their external environment, and even their parental ancestry. Additionally, cutting edge research examining the functional mechanisms of many neurohormonal signals (e.g., leptin and insulin), which have long been known to contribute to obesity, are shedding new light on how dysregulation of these systems can lead to pathological changes in feeding circuitry in the brain. Ongoing research will continue to tie all of these seemingly disparate areas of research together and may someday help us to understand how our environment and our bodies may influence our brains to make people prone to obesity. Given the evergrowing obesity epidemic, and the consequential toll this takes on the health system, these lines of research should receive greater attention in the coming years.

\section{References}

Balsalobre A (2002) Clock genes in mammalian peripheral tissues. Cell Tissue Res 309:193-199. CrossRef Medline

Balsalobre A, Brown SA, Marcacci L, Tronche F, Kellendonk C, Reichardt HM, Schütz G, Schibler U (2000) Resetting of circadian time in peripheral tissues by glucocorticoid signaling. Science 289:2344-2347. CrossRef Medline

Bass J (2012) Circadian topology of metabolism. Nature 491:348-356. CrossRef Medline

Bass J, Takahashi JS (2010) Circadian integration of metabolism and energetics. Science 330:1349-1354. CrossRef Medline

Buijs RM, Kalsbeek A (2001) Hypothalamic integration of central and peripheral clocks. Nat Rev Neurosci 2:521-526. CrossRef Medline

Chadwick B, Miller M, Hurd Y (2013) Cannabis use during adolescent development: susceptibility to psychiatric illness. Front Psychiatry 4:129. CrossRef

Champagne FA (2010) Epigenetic influence of social experiences across the lifespan. Dev Psychobiol 52:299-311. CrossRef Medline

Chavez M, Seeley RJ, Woods SC (1995) A comparison between effects of intraventricular insulin and intraperitoneal lithium chloride on three measures sensitive to emetic agents. Behav Neurosci 109:547-550. CrossRef Medline

Chioccarelli T, Cacciola G, Altucci L, Lewis SE, Simon L, Ricci G, Ledent C, Meccariello R, Fasano S, Pierantoni R, Cobellis G (2010) Cannabinoid receptor 1 influences chromatin remodeling in mouse spermatids by affecting content of transition protein 2 mRNA and histone displacement. Endocrinology 151:5017-5029. CrossRef Medline

Correia ML, Haynes WG, Rahmouni K, Morgan DA, Sivitz WI, Mark AL (2002) The concept of selective leptin resistance: evidence from agouti yellow obese mice. Diabetes 51:439-442. CrossRef Medline

Cravatt BF, Demarest K, Patricelli MP, Bracey MH, Giang DK, Martin BR, Lichtman AH (2001) Supersensitivity to anandamide and enhanced endogenous cannabinoid signaling in mice lacking fatty acid amide hydrolase. Proc Natl Acad Sci U S A 98:9371-9376. CrossRef Medline

Curley JP, Mashoodh R, Champagne FA (2011) Epigenetics and the origins of paternal effects. Horm Behav 59:306-314. CrossRef Medline

Davis JF, Choi DL, Schurdak JD, Fitzgerald MF, Clegg DJ, Lipton JW, Figlewicz DP, Benoit SC (2011) Leptin regulates energy balance and motivation through action at distinct neural circuits. Biol Psychiatry 69:668-674. CrossRef Medline

Dietz DM, Laplant Q, Watts EL, Hodes GE, Russo SJ, Feng J, Oosting RS, 
Vialou V, Nestler EJ (2011) Paternal transmission of stress-induced pathologies. Biol Psychiatry 70:408-414. CrossRef Medline

Di Marzo V, Goparaju SK, Wang L, Liu J, Bátkai S, Járai Z, Fezza F, Miura GI, Palmiter RD, Sugiura T, Kunos G (2001) Leptin-regulated endocannabinoids are involved in maintaining food intake. Nature 410:822-825. CrossRef Medline

Dinieri JA, Hurd YL (2012) Rat models of prenatal and adolescent cannabis exposure. Methods Mol Biol 829:231-242. CrossRef Medline

Dunn GA, Bale TL (2009) Maternal high-fat diet promotes body length increases and insulin insensitivity in second-generation mice. Endocrinology 150:4999-5009. CrossRef Medline

Dunn GA, Bale TL (2011) Maternal high-fat diet effects on third-generation female body size via the paternal lineage. Endocrinology 152:2228-2236. CrossRef Medline

Dunn GA, Morgan CP, Bale TL (2011) Sex-specificity in transgenerational epigenetic programming. Horm Behav 59:290-295. CrossRef Medline

Fick LJ, Belsham DD (2010) Nutrient sensing and insulin signaling in neuropeptide-expressing immortalized, hypothalamic neurons: a cellular model of insulin resistance. Cell Cycle 9:3186-3193. CrossRef Medline

Figlewicz DP, Sipols AJ, Seeley RJ, Chavez M, Woods SC, Porte D Jr (1995) Intraventricular insulin enhances the meal-suppressive efficacy of intraventricular cholecystokinin octapeptide in the baboon. Behav Neurosci 109:567-569. CrossRef Medline

Fulton S, Pissios P, Manchon RP, Stiles L, Frank L, Pothos EN, Maratos-Flier E, Flier JS (2006) Leptin regulation of the mesoaccumbens dopamine pathway. Neuron 51:811-822. CrossRef Medline

Hommel JD, Trinko R, Sears RM, Georgescu D, Liu ZW, Gao XB, Thurmon JJ, Marinelli M, DiLeone RJ (2006) Leptin receptor signaling in midbrain dopamine neurons regulates feeding. Neuron 51:801-810. CrossRef Medline

Horvath TL, Diano S, Sotonyi P, Heiman M, Tschöp M (2001) Minireview: ghrelin and the regulation of energy balance-a hypothalamic perspective. Endocrinology 142:4163-4169. CrossRef Medline

Jamshidi N, Taylor DA (2001) Anandamide administration into the ventromedial hypothalamus stimulates appetite in rats. Br J Pharmacol 134: 1151-1154. CrossRef Medline

Jimenez-Chillaron JC, Isganaitis E, Charalambous M, Gesta S, PentinatPelegrin T, Faucette RR, Otis JP, Chow A, Diaz R, Ferguson-Smith A, Patti ME (2009) Intergenerational transmission of glucose intolerance and obesity by in utero undernutrition in mice. Diabetes 58:460-468. CrossRef Medline

Jirtle RL, Skinner MK (2007) Environmental epigenomics and disease susceptibility. Nat Rev Genet 8:253-262. CrossRef Medline

Jutras-Aswad D, DiNieri JA, Harkany T, Hurd YL (2009) Neurobiological consequences of maternal cannabis on human fetal development and its neuropsychiatric outcome. Eur Arch Psychiatry Clin Neurosci 259:395412. CrossRef Medline

Kaati G, Bygren LO, Pembrey M, Sjöstrom M (2007) Transgenerational response to nutrition, early life circumstances and longevity. Eur J Hum Genet 15:784-790. CrossRef Medline

Karatsoreos IN, Bhagat S, Bloss EB, Morrison JH, McEwen BS (2011) Disruption of circadian clocks has ramifications for metabolism, brain, and behavior. Proc Natl Acad Sci U S A 108:1657-1662. CrossRef Medline

Kenny PJ (2011) Reward mechanisms in obesity: new insights and future directions. Neuron 69:664-679. CrossRef Medline

Kohno D, Yada T (2012) Arcuate NPY neurons sense and integrate peripheral metabolic signals to control feeding. Neuropeptides 46:315-319. CrossRef Medline

Könner AC, Brüning JC (2012) Selective insulin and leptin resistance in metabolic disorders. Cell Metab 16:144-152. CrossRef Medline

Labouèbe G, Liu S, Dias C, Zou H, Wong JC, Karunakaran S, Clee SM, Phillips AG, Boutrel B, Borgland SL (2013) Insulin induces long-term depression of ventral tegmental area dopamine neurons via endocannabinoids. Nat Neurosci 16:300-308. CrossRef Medline

Marcheva B, Ramsey KM, Buhr ED, Kobayashi Y, Su H, Ko CH, Ivanova G, Omura C, Mo S, Vitaterna MH, Lopez JP, Philipson LH, Bradfield CA, Crosby SD, JeBailey L, Wang X, Takahashi JS, Bass J (2010) Disruption of the clock components CLOCK and BMAL1 leads to hypoinsulinaemia and diabetes. Nature 466:627-631. CrossRef Medline
Mark AL, Correia ML, Rahmouni K, Haynes WG (2002) Selective leptin resistance: a new concept in leptin physiology with cardiovascular implications. J Hypertens 20:1245-1250. CrossRef Medline

Mashoodh R, Franks B, Curley JP, Champagne FA (2012) Paternal social enrichment effects on maternal behavior and offspring growth. Proc Natl Acad Sci U S A 109 [Suppl 2]:17232-17238. CrossRef Medline

Mebel DM, Wong JC, Dong YJ, Borgland SL (2012) Insulin in the ventral tegmental area reduces hedonic feeding and suppresses dopamine concentration via increased reuptake. Eur J Neurosci 36:2336-2346. CrossRef Medline

Mendoza J, Graff C, Dardente H, Pevet P, Challet E (2005) Feeding cues alter clock gene oscillations and photic responses in the suprachiasmatic nuclei of mice exposed to a light/dark cycle. J Neurosci 25:1514-1522. CrossRef Medline

Myers MG, Cowley MA, Münzberg H (2008) Mechanisms of leptin action and leptin resistance. Annu Rev Physiol 70:537-556. CrossRef Medline

Pembrey ME, Bygren LO, Kaati G, Edvinsson S, Northstone K, Sjöström M, Golding J, Team AS (2006) Sex-specific, male-line transgenerational responses in humans. Eur J Hum Genet 14:159-166. CrossRef Medline

Pentinat T, Ramon-Krauel M, Cebria J, Diaz R, Jimenez-Chillaron JC (2010) Transgenerational inheritance of glucose intolerance in a mouse model of neonatal overnutrition. Endocrinology 151:56175623. CrossRef Medline

Phillips DI, Barker DJ, Fall CH, Seckl JR, Whorwood CB, Wood PJ, Walker BR (1998) Elevated plasma cortisol concentrations: a link between low birth weight and the insulin resistance syndrome? J Clin Endocrinol Metab 83:757-760. CrossRef Medline

Phillips DI, Walker BR, Reynolds RM, Flanagan DE, Wood PJ, Osmond C, Barker DJ, Whorwood CB (2000) Low birth weight predicts elevated plasma cortisol concentrations in adults from 3 populations. Hypertension 35:1301-1306. CrossRef Medline

Reynolds RM, Walker BR, Syddall HE, Andrew R, Wood PJ, Whorwood CB, Phillips DI (2001) Altered control of cortisol secretion in adult men with low birth weight and cardiovascular risk factors. J Clin Endocrinol Metab 86:245-250. CrossRef Medline

Roseberry AG, Painter T, Mark GP, Williams JT (2007) Decreased vesicular somatodendritic dopamine stores in leptin-deficient mice. J Neurosci 27:7021-7027. CrossRef Medline

Saini C, Morf J, Stratmann M, Gos P, Schibler U (2012) Simulated body temperature rhythms reveal the phase-shifting behavior and plasticity of mammalian circadian oscillators. Genes Dev 26:567-580. CrossRef Medline

Silvestri C, Di Marzo V (2013) The endocannabinoid system in energy homeostasis and the etiopathology of metabolic disorders. Cell Metab 17: 475-490. CrossRef Medline

Sipols AJ, Bayer J, Bennett R, Figlewicz DP (2002) Intraventricular insulin decreases $\kappa$ opioid-mediated sucrose intake in rats. Peptides 23:21812187. CrossRef Medline

Stice E, Figlewicz DP, Gosnell BA, Levine AS, Pratt WE (2012) The contribution of brain reward circuits to the obesity epidemic. Neurosci Biobehav Rev. Advance online publication. Retrieved Dec. 10, 2012. doi: 10.1016/j.neubiorev.2012.12.001. CrossRef Medline

Stuber GD, Klanker M, de Ridder B, Bowers MS, Joosten RN, Feenstra MG, Bonci A (2008) Reward-predictive cues enhance excitatory synaptic strength onto midbrain dopamine neurons. Science 321:1690-1692. CrossRef Medline

Thaler JP, Schwartz MW (2010) Minireview: inflammation and obesity pathogenesis - the hypothalamus heats up. Endocrinology 151:41094115. CrossRef Medline

Thaler JP, Yi CX, Schur EA, Guyenet SJ, Hwang BH, Dietrich MO, Zhao X, Sarruf DA, Izgur V, Maravilla KR, Nguyen HT, Fischer JD, Matsen ME, Wisse BE, Morton GJ, Horvath TL, Baskin DG, Tschöp MH, Schwartz MW (2012) Obesity is associated with hypothalamic injury in rodents and humans. J Clin Invest 122:153-162. CrossRef Medline

Thompson JL, Borgland SL (2013) Presynaptic leptin action suppresses excitatory synaptic transmission onto ventral tegmental area dopamine neurons. Biol Psychiatry 73:860-868. CrossRef Medline

Tomasiewicz HC, Jacobs MM, Wilkinson MB, Wilson SP, Nestler EJ, Hurd 
YL (2012) Proenkephalin mediates the enduring effects of adolescent cannabis exposure associated with adult opiate vulnerability. Biol Psychiatry 72:803-810. CrossRef Medline

Trinko R, Gan G, Gao XB, Sears RM, Guarnieri DJ, DiLeone RJ (2011) Erk1/2 mediates leptin receptor signaling in the ventral tegmental area. PLoS One 6:e27180. CrossRef Medline

Turek FW, Joshu C, Kohsaka A, Lin E, Ivanova G, McDearmon E, Laposky A, Losee-Olson S, Easton A, Jensen DR, Eckel RH, Takahashi JS, Bass J (2005) Obesity and metabolic syndrome in circadian Clock mutant mice. Science 308:1043-1045. CrossRef Medline

Velloso LA, Schwartz MW (2011) Altered hypothalamic function in dietinduced obesity. Int J Obes 35:1455-1465. CrossRef Medline

Wilding JP (2002) Neuropeptides and appetite control. Diabet Med 19: 619-627. CrossRef Medline
Williams G, Bing C, Cai XJ, Harrold JA, King PJ, Liu XH (2001) The hypothalamus and the control of energy homeostasis: different circuits, different purposes. Physiol Behav 74:683-701. CrossRef Medline

Williams KW, Elmquist JK (2012) From neuroanatomy to behavior: central integration of peripheral signals regulating feeding behavior. Nat Neurosci 15:1350-1355. CrossRef Medline

Woods SC, Seeley RJ, Baskin DG, Schwartz MW (2003) Insulin and the blood-brain barrier. Curr Pharm Des 9:795-800. CrossRef Medline

Youngson NA, Morris MJ (2013) What obesity research tells us about epigenetic mechanisms. Philo Trans R Soc Lond B Biol Sci 368:20110337. CrossRef

Zigman JM, Elmquist JK (2003) Minireview: from anorexia to obesity - the yin and yang of body weight control. Endocrinology 144:3749-3756. CrossRef Medline 